\title{
Scent marking in wolves Canis lupus inhabiting managed lowland forests in Poland
}

\author{
Kinga M. Stępniak ${ }^{1}$ (1) • Natalia Niedźwiecka ${ }^{2} \cdot$ Maciej Szewczyk $^{3}$ (D) $\cdot$ Robert W. Mysłajek $^{4}$ (D)
}

Received: 25 August 2019 / Accepted: 2 June 2020 / Published online: 13 June 2020

(C) The Author(s) 2020

\begin{abstract}
In wolves Canis lupus, scent marking plays an important role in territory defence. In Europe, studies on patterns of scent marking in wolves have mostly been conducted in mountains or primeval forests, but since these areas are characterised by low human activity, the impact of people on this behaviour has been neglected. We conducted a study that combined genetic methods with an analysis of the spatial distribution of wolf territory markings in lowland managed forests with high human activity. We found that scent markings are deposited by all members of wolf family groups. Wolves most intensively marked crossroads and their vicinity, especially on roads only accessible for four-wheel drive cars. Our study provides further evidence that crossroads of forest roads play a crucial role in wolf scent marking. The results of our study may be useful during inventories of wolf populations based on collecting indirect signs of their presence or non-invasive genetic sampling.
\end{abstract}

Keywords Canis lupus $\cdot$ Scent marking $\cdot$ Wolves $\cdot$ Crossroads $\cdot$ Forest roads

\section{Introduction}

The wolf population went through a steep historical decline, but recently, the wolf's key ecological role has been increasingly recognized, leading to the introduction of conservation programs (Mysłajek and Nowak 2015), creation of protected areas (Diserens et al. 2017), and its reintroduction to several places (Fritts et al. 1997). As a result, wolf numbers have increased both in Europe (Chapron et al. 2014) and North America (Phillips et al. 2004). This increase in wolf populations coincides with recolonisation of landscapes dominated

Communicated by: Karol Zub

Kinga M. Stępniak

kinga.stepniak@igib.uw.edu.pl

1 Institute of Genetics and Biotechnology, Faculty of Biology, University of Warsaw, Pawińskiego 5a, 02-106 Warszawa, Poland

2 Association for Nature "Wolf", Cynkowa 4, 34-324 Twardorzeczka, Poland

3 Department of Vertebrate Ecology and Zoology, Faculty of Biology, University of Gdańsk, Wita Stwosza 59, 80-308 Gdańsk, Poland

4 Department of Ecology, Institute of Functional Biology and Ecology, Faculty of Biology, University of Warsaw, Biological and Chemical Research Centre, Żwirki i Wigury 101, 02-089 Warszawa, Poland and shaped by humans (Kuijper et al. 2016). Wolves are the most widely distributed large carnivore species with which humans share the landscape (Mech and Boitani 2003). Although living close to humans can provide benefits to wolves in the form of human-derived resources (Newsome et al. 2015), the fear of humans as an apex predator can negatively impact large carnivores. Risk correlated with human presence can impact wolf movements, which may limit hunting and feeding behaviour (Berger 2007; Kuijper et al. 2016; Suraci et al. 2019). Wolf breeding site selection is strongly influenced by the perceived risk toward humans (Iliopoulos et al. 2014; Sazatornil et al. 2016). In forests, wolves also avoid human presence (traffic, forestry operations) by temporarily selecting areas far from people (Theuerkauf et al. 2003). That suggests scent marking behaviour may also be altered by human presence.

Wolf conservation, including management of the areas they inhabit, requires good knowledge on their number and distribution (Boitani et al. 2015). Unfortunately, monitoring of wolves is challenging, as they live in low densities, utilize vast territories (Mysłajek et al. 2018), and young individuals disperse over large distances (Andersen et al. 2015). Modern techniques, like telemetry, enable precise assessment of population parameters, but in contrast to North America, in Europe, such tools are generally only used in short-term local studies on limited numbers of individuals (e.g. Ciucci et al. 
1997; Blanco et al. 2005; Kusak et al. 2005; Jędrzejewski et al. 2007; Mysłajek et al. 2018), with the exception of Scandinavia and Finland (Mattisson et al. 2013; Kojola et al. 2018). Different techniques give different types of information: telemetry gives information about individual space use and activity (Merrill 2002; Demma et al. 2007), while camera traps can be used to access information about pack size and space use by all family group members (Campos-Candela et al. 2017). However, it is often expensive to collect sufficient good quality data using these techniques, and in the case of telemetry, in countries where wolves are protected by law (like Poland), obtaining permissions to perform this kind of research can be time consuming. Cheaper and simpler methods of wolf monitoring at the landscape level are based on recording indirect signs of their presence, like the secretions (scats, urine) they use for olfactory communication. Sign counts have been used as an index of relative abundance of large carnivores (Llaneza et al. 2014). Molecular techniques are of prime importance in conservation genetics and behavioural ecology, and these can be added to increase the power of monitoring efforts Studies using genetic techniques based on non-invasive sampling are becoming increasingly popular (Fabbri et al. 2007; Steinglein et al. 2010). Thus, knowledge about patterns of scent marking is crucial for monitoring efforts to be successful.

Wolves mark territories using faeces, urine and secretions from glands between the toes deposited during ground scratching (Harrington and Asa 2003). Territory marking plays an important role in territory defence, pair bonding and achieving reproductive synchrony (Peters and Mech 1975; Rothman and Mech 1979; Harrington 1981; Asa et al. 1984; Paquet and Fuller 1990; Paquet 1991; Vilà et al. 1994). Intensity of scent marking varies seasonally, and is affected by the physiological status of individuals and interactions with conspecifics (Kleiman 1966; Peters and Mech 1975; Asa et al. 1990; Zub et al. 2003). Wolves increase the probability of scent mark detection by other individuals by depositing secretions in conspicuous places (Barja et al. 2004, 2005). Previous studies, conducted in North America, have suggested that wolves primarily mark the boundaries of their territory (olfactory bowl model, Peters and Mech 1975); however, more recent findings have revealed that some of the most important parts of their territory, e.g. the vicinity of den sites, are also intensively marked (hot spot model, Zub et al. 2003; Llaneza et al. 2014).

In Europe, studies on scent marking in wolves have mostly been conducted in mountains (Vilà et al. 1994; Barja et al. 2004, 2005, 2008a, b; Martín et al. 2010; Llaneza et al. 2014) or primeval forests (Zub et al. 2003), while managed forests, the primary habitat for wolves in the Northern European Plains (Jędrzejewski et al. 2008; Huck et al. 2011; Nowak et al. 2017), have been neglected. As human presence can be the overriding factor driving wolf behaviour and space use (Theuerkauf et al. 2003; Iliopoulos et al. 2014; Sazatornil et al. 2016; Kuijper et al. 2016; Suraci et al. 2019), we aimed to assess patterns of wolf territory marking with scats and urine in intensively managed lowland forests. Following the studies of Barja et al. $(2004,2005)$, we hypothesised that wolves will deposit their faeces and urine in places where they are more likely to be detected by other individuals, like at or near forest road intersections. We expect also that to maximize the effectiveness of their markings, wolves will use different types of forest road intersections, characterised by lower anthropopression then in Barja et al. (2004). There is almost no difference between the numbers of markings left inside forests, and along roads or paths (Zub et al. 2003), so as roads are often used by wolves, we chose to survey them, focusing on their usefulness in forest management. Notably, we used a novel approach combining the traditional way of analysing scent marking behaviour with non-invasive genetic techniques to reveal the role of an individual's sex and social status in territory marking.

\section{Methods}

\section{Study area}

We conducted the study in Napiwoda-Ramuki Forest (hereinafter NRF) in northwest Poland $\left(53^{\circ} 33^{\prime} 40^{\prime \prime}-53^{\circ} 14^{\prime} 42^{\prime \prime} \mathrm{N}\right.$, $20^{\circ} 33^{\prime} 23^{\prime \prime}-20^{\circ} 56^{\prime} 59^{\prime \prime} \mathrm{E}$ ) (Fig. 1). The area lies within four Forest Districts (Nidzica, Szczytno, Przasnysz, Wielbark). The terrain $\left(1300 \mathrm{~km}^{2}\right)$ is flat with a few small hills reaching up to $200 \mathrm{~m}$ above sea level. The climate is continental, with a long persistence of snow cover (94 days/year), and average temperatures in January and July of -3.1 and $16.8{ }^{\circ} \mathrm{C}$, respectively. The forests are commercial stands dominated by relatively young (mostly 40-80-year old) planted Scots pines Pinus sylvestris (85\%), while wetter patches are mainly overgrown with black alder Alnus glutinosa (8\%).

Although the ungulate community in NRF consists of four large herbivore species, including moose Alces alces, red deer Cervus elaphus, roe deer Capreolus capreolus and wild boar Sus scrofa (Borowik et al. 2013), wolves in this area mainly prey on roe deer and wild boar, with additional food items being brown hare and Eurasian beaver (Jędrzejewski et al. 2012). Wolves inhabiting NRF belong to the Baltic wolf population, which is the source of the Central European wolf population that is currently recovering in western Poland, Germany, western Czech Republic, The Netherlands and Denmark (Czarnomska et al. 2013; Szewczyk et al. 2019). The study area is occupied by three wolf family groups (Gełdoń et al. 2015, K.M. Stepniak unpubl.). The area is also sparsely inhabited by the Eurasian lynx Lynx lynx (Niedziałkowska et al. 2006). The study area encompasses the former military training area "Muszaki", and due to their 


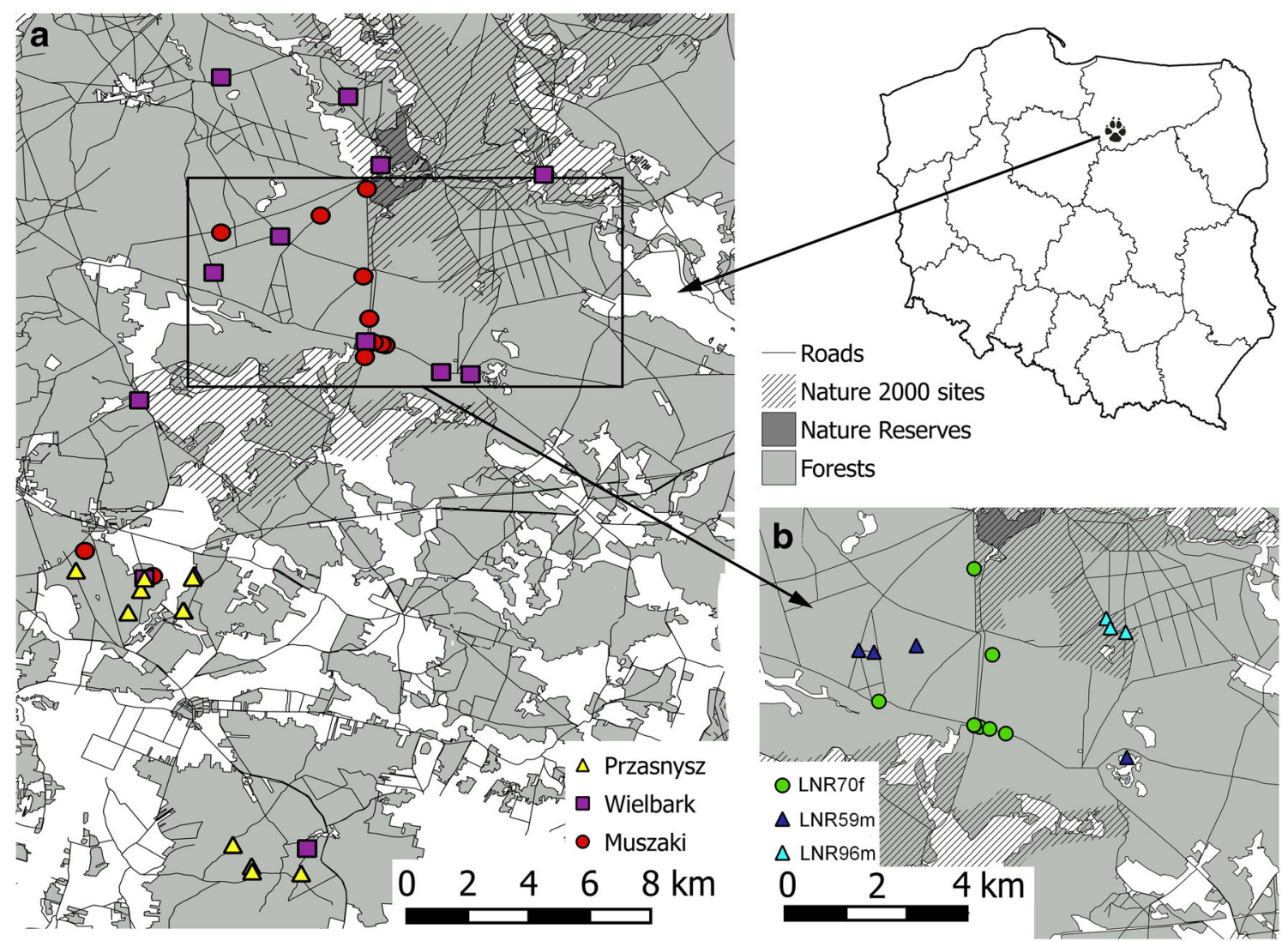

Fig. 1 Map of the study area. a Location of scent markings left by wolves genetically assigned to three local family groups, called Przasnysz (yellow triangles), Wielbark (violet squares) and Muszaki (red circles). b Location of scent markings left by wolves that were not assigned to any

commercial use, local forests are intersected by a dense network of gravel and dirt roads. However, the use of roads administrated by State Forest Service is mainly limited to forestry operations, and public access is restricted.

\section{Genetic analysis}

We performed genetic analysis to assess the sex, numbers and genetic relationships of wolves using DNA isolated from noninvasive samples. Only samples with sufficient quality DNA (101 scats and 20 urinations) were used in these analyses. Samples were collected during the winter from December 2016 to March 2018. Due to the low number of days with snow cover in the study period, the opportunities for finding urine samples were limited.

We stored 3-4-cm fragments of fresh scats in plastic tubes $(30 \mathrm{ml})$ filled with $96 \%$ ethyl alcohol, while urine was collected together with the snow on which it was left and placed into $50-\mathrm{ml}$ plastic tubes with $30 \mathrm{ml} \mathrm{96 \%} \mathrm{ethyl} \mathrm{alcohol} \mathrm{and} 1.5 \mathrm{ml}$ $3 \mathrm{M}$ sodium acetate.

We isolated DNA from faecal samples using an Exgene ${ }^{\mathrm{TM}}$ Stool DNA mini kit (GeneAll, Korea) and from urine using an Exgene $^{\mathrm{TM}}$ Genomic DNA Micro kit (GeneAll, Korea) family group (i.e. putative floaters), a female called LNR70f (green circles) and two males LNR59m and LNR96m (dark blue and light blue circles, respectively)

following the manufacturer's instructions. Each DNA extract was amplified three times in PCR reactions. To reduce the risk of contamination, we carried out DNA extractions in a room dedicated to the processing of non-invasive samples. We included negative controls in each extraction set to monitor for contamination.

We amplified the following unlinked autosomal microsatellites previously used by members of the Central European Wolf Consortium to study wolf population genetics (de Groot et al. 2016): PEZ17 (Neff et al. 1999), CPH5 (Fredholm and Wintero 1995), vWF (Shibuya et al. 1994), FH2001, FH2010, FH2017, FH2137, FH2088, FH2096, FH2097, FH2140, FH2054, FH2161 (Francisco et al. 1996). We also amplified DBX intron 6 and DBY intron 7 fragments to determine the sexes of individuals. We performed multiplex PCRs in a $10-\mu$ l solution containing HotStarTaq Master Mix (Qiagen), each primer at $0.2 \mu \mathrm{M}$ concentration, $0.2 \mathrm{mg} / \mathrm{ml}$ $\mathrm{BSA}$, and $3.8 \mu \mathrm{l}$ of DNA isolate. Amplification reactions were carried out in an MJResearch Dyad PTC-220 Peltier Thermal Cycler (BioRad) (for further details, see Lesniak et al. 2017). The products of PCR reactions were analysed on an ABI3130 DNA Analyzer (LifeTechnologies, USA) and fragment sizes were determined using PeakScanner (Applied Biosystems, 


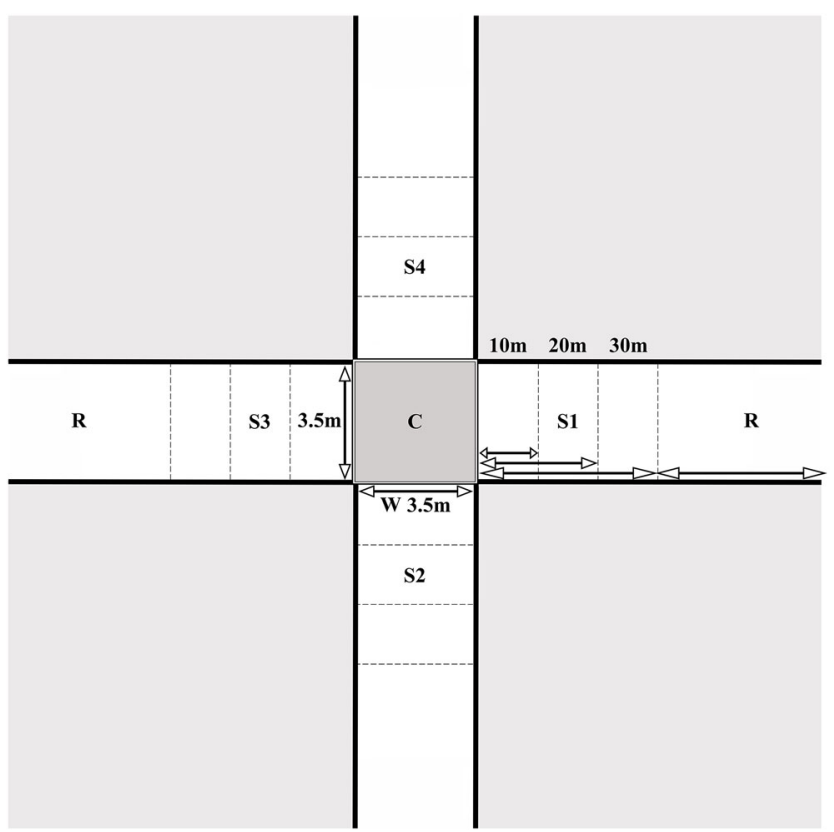

Fig. 2 Description of a forest road intersection. Grey area indicates the surface of the crossroad, lined area the surface of the periphery of the crossroad and white area roads; $S_{\mathrm{n}}$ is the number of roads leaving the crossroad

USA). Each scat sample was amplified at least three times through a multiple-tube approach (Taberlet et al. 1996). We accepted alleles confirmed by a minimum of two independent PCR amplifications, and in subsequent analyses included only individuals for which nine or more loci had been successfully amplified. We assessed relatedness of individuals using software for analysing parentage from co-dominant genetic markers such as microsatellites: Cervus (Kalinowski et al. 2007) and Colony (Jones and Wang 2010).

\section{Assessment of scent marking patterns}

We conducted studies on wolf scent marking from December 2016 to March 2017. In this period, we made 18 transects, with a total length of $110.93 \mathrm{~km}(\mathrm{~T})$ and checked forest intersections 436 times (C) (Table 3). We inspected $5.34 \mathrm{~km}$ of crossroads, $30.56 \mathrm{~km}$ of peripheries of crossroads and $352.36 \mathrm{~km}$ of roads. When we checked the same intersection more than once, only markings deposited after our last check were considered to be new markings. The average width (W) of roads was $3.5 \mathrm{~m}$. The locations of scent markings (scats and urinations) of wolves were recorded with a hand-held GPS unit (GPSMAP 64st, Garmin, USA). A description of each marking's surroundings was made using the following parameters (Fig. 2): (1) location of marking: on road, on crossroad or on periphery of crossroad; (2) distance between marking and border of intersection; (3) driveability: type 1 (high, easy crossroad) - road without obstacles, easily accessible for every type of car, type 2 (medium, medium crossroad) - road with small obstacles that make driving harder for a two-wheel drive car, type 3 (low, difficult crossroad) - road traversable only with a four-wheel drive vehicle; and (4) type of intersection. When intersections were composed of roads with different driveabilities, they were classified by the least driveable road. We additionally divided intersections into type 1 (simple) with a maximum of three exit roads, and type 2 (multiple) with four, five or six exit roads. We assumed a "crossroad" (Fig. 2) to be a square with side lengths equal to the average width of roads. We calculated the total area of crossroads surveyed with the formula $T_{\mathrm{c}}=W^{2} \times \Sigma C$. The area from the border of a crossroad to $30 \mathrm{~m}$ away was defined as the "periphery of a crossroads". We divided this area into three parts: $0-10 \mathrm{~m}, 11-20 \mathrm{~m}$ and $21-30 \mathrm{~m}$ from the border of the crossroad. We calculated the total area with the formula $T_{\mathrm{s}}=$ $W \times \Sigma S \times L$. The area outside crossroads and its peripheries was categorised as "road". The formula for this calculation was $T_{\mathrm{r}}=T_{\mathrm{t}}-\left(T_{\mathrm{c}}+T_{\mathrm{s}}\right)$. We calculated the total studied area with the formula $T_{\mathrm{t}}=T \times 3.5$. We always surveyed the entire area of crossroads, crossroad peripheries and roads. To facilitate comparisons, all formulas for area calculations and driveability categories are modelled on Barja et al. (2004).

\section{Results}

\section{Wolf population within study area}

We genetically identified 25 wolves within the study area: 17 males and 8 females, which left 34 and 23 markings, respectively (Table 1$)$. We obtained 2.0 samples per male $\left(\chi^{2}=\right.$ $0.468, d f=1, P>0.05)$ and 2.9 samples per female $\left(\chi^{2}=1\right.$, $d f=1, P>0.05$ ), but there were no statistical differences between the numbers of samples and expected values. We found three highly related groups (Wielbark, Przasnysz, and Muszaki groups) and several individuals that were not related to any of the three family group members, probably floaters (Fig. 1b). From the Wielbark group, we identified seven individuals, including the breeding male and six of his offspring. From the Przasnysz group, we identified six individuals, including the breeding pair and four of their offspring. From the Muszaki group, we identified seven individuals, including the breeding female and six of her offspring (Table 1).

The largest numbers of markings were left by two individuals unrelated to either of identified groups - female LNR70F and male LNR59M (Table 2). In winter 2017, female LNR70F left 11 markings on one of the biggest roads and on one of the biggest crossroads in the study area-mostly urine with blood, which suggests that she was in heat. At the same time, LNR59M left five markings, also mostly urine, near the markings of LNR70F. We identified three more unrelated individuals - male $132 \mathrm{M}$ who left a scat on Przasnysz 
Table 1 Number of scent markings left by individuals identified by the analysis of 13 microsatellite loci

\begin{tabular}{|c|c|c|c|c|}
\hline Family & Individual & Sex & Number of $\mathrm{m}$. w. scats & Number of $\mathrm{m}$. w. urine \\
\hline Muszaki & LNR36F* & Female & 1 & 0 \\
\hline Muszaki & LNR60M & Male & 1 & 4 \\
\hline Muszaki & LNR102F & Female & 1 & 0 \\
\hline Muszaki & LNR144M & Male & 1 & 0 \\
\hline Muszaki & LNR111M & Male & 2 & 0 \\
\hline Muszaki & LNR52F & Female & 1 & 0 \\
\hline Muszaki & LNR108M & Male & 1 & 0 \\
\hline Total & 7 & $3 \mathrm{~F} / 4 \mathrm{M}$ & 8 & 4 \\
\hline Przasnysz & LNR46M* & Male & 2 & 0 \\
\hline Przasnysz & LNR34F* & Female & 1 & 0 \\
\hline Przasnysz & LNR49F & Female & 2 & 0 \\
\hline Przasnysz & LNR119M & Male & 2 & 0 \\
\hline Przasnysz & LNR129F & Female & 3 & 0 \\
\hline Przasnysz & LNR48M & Male & 2 & 0 \\
\hline Total & 6 & $3 \mathrm{~F} / 3 \mathrm{M}$ & 12 & 0 \\
\hline Wielbark & LNR69M* & Male & 1 & 0 \\
\hline Wielbark & LNR151M & Male & 3 & 0 \\
\hline Wielbark & LNR76M & Male & 0 & 2 \\
\hline Wielbark & LNR98F & Female & 3 & 0 \\
\hline Wielbark & LNR130M & Male & 1 & 0 \\
\hline Wielbark & LNR49M & Male & 1 & 0 \\
\hline Wielbark & LNR127M & Male & 1 & 0 \\
\hline Total & 7 & $1 \mathrm{~F} / 6 \mathrm{M}$ & 10 & 2 \\
\hline unknown & LNR70F & Female & 3 & 8 \\
\hline unknown & LNR59M & Male & 1 & 4 \\
\hline unknown & LNR96M & Male & 1 & 0 \\
\hline unknown & LNR85M & Male & 0 & 3 \\
\hline unknown & LNR132M & Male & 1 & 0 \\
\hline Total & 5 & $1 \mathrm{~F} / 4 \mathrm{M}$ & 6 & 15 \\
\hline
\end{tabular}

A star symbol $(*)$ denotes the most probable breeding individual. Relationship between individuals and their status in family group was determined in Cervus (Kalinowski et al. 2007) and Colony (Jones and Wang 2010) software group's territory and two others, LNR85M and LNR96Mboth marked with urine near the markings of LNR70F.

\section{Locations of wolf markings}

We inspected 436 forest intersections and only $26 \%(n=112)$ of them was marked. In total we found 130 markings. Their density $\left(\mathrm{n} / \mathrm{km}^{2}\right)$ was highest in the peripheries of crossroads (3.4 samples, avg. $=5.61, \mathrm{SE} \pm 0.19)$, medium on crossroads $(1.5$, avg. $=0.44, \mathrm{SE} \pm 0.45)$ and lowest on roads $(0.15$, avg. $=$ $1, \mathrm{SE} \pm 0.10)$. The total density of markings at crossroads and their peripheries (these categories were combined due to the small number of samples) was much larger $\left(\chi^{2}=840.1951\right.$,

Table 2 Number of markings, expected and observed frequencies of wolf markings left by related and unrelated individuals

\begin{tabular}{lllllll}
\hline & Number of individuals & \multicolumn{2}{l}{ Markings } & & \multicolumn{2}{l}{ Frequency } \\
& & Scat & Urine & & Observed & Expected \\
\hline Related & 20 & 30 & 6 & & 36 & 45.6 \\
Unrelated & 5 & 6 & 15 & 21 & 11.4 \\
Total & 25 & 36 & 21 & & 57 & 57 \\
\hline
\end{tabular}

$d f=2, P<0.001)$ than the expected value, while the density of markings on roads was significantly lower $\left(\chi^{2}=83.8824, d f\right.$ $=2, P<0.001)($ Table 3$)$. We found a significantly higher number of markings than expected at multiple intersections (56 markings on 186 crossroads surveyed) $\left(\chi^{2}=19.185\right.$, $d f$ $=1, P<0.001)$. At simple intersection, the number of markings was lower than expected (19 markings on 252 crossroads surveyed) $\left(\chi^{2}=13.002, d f=1, P<0.001\right)$.

The most marked were intersections with medium driveability (56 markings on 213 crossroads). The frequency of markings on this type of intersection was higher than expected $\left(\chi^{2}=10.19, d f=1, P<0.001\right)$. On the other hand, at the crossroads with low driveability, the marking frequency was lower than expected $\left(\chi^{2}=10.42, d f=1, P<0.001\right)$. For the high driveability type, we found no statistical difference between the expected and observed frequencies $\left(\chi^{2}=0.08, d f=1\right.$, $P>0.05)$. Moreover, this type of intersection was the least frequently marked (Fig. 5).

Markings were not deposited randomly. Their number decreased with distance from the border of crossroads: $65 \%$ were deposited between 1 and $10 \mathrm{~m}$ away from the border, $28.2 \%$ between 10 and $20 \mathrm{~m}$ and only $6.3 \%$ between 20 and $30 \mathrm{~m}$ (Fig. 3). Separately, most urine markings were between 1 and $10 \mathrm{~m}(73 \%)$ away, then $16.1 \%$ between $10 \mathrm{~m}$ and $20 \mathrm{~m}$ 
Table 3 Expected and observed frequencies of wolf markings in the two types of area: crossroads with their peripheries and roads

\begin{tabular}{llll}
\hline & \multicolumn{2}{l}{ Frequency } & \multirow{2}{*}{ Kilometres Surveyed } \\
\cline { 2 - 3 } & Observed & Expected & \\
\hline Crossroads $\left(T_{\mathrm{c}}\right)$ and periphery of crossroads $(T \mathrm{~s})$ & 112 & 12.02 & 35.89 \\
Roads $\left(T_{\mathrm{r}}\right)$ & 18 & 117.98 & 352.36 \\
Total $\left(T_{\mathrm{t}}\right)$ & 130 & 130 & 388.25 \\
\hline
\end{tabular}

and $10.9 \%$ between $20 \mathrm{~m}$ and $30 \mathrm{~m}$. The number of scat markings also decreased with distance: $62.1 \%$ were between 1 and $10 \mathrm{~m}, 34.5 \%$ between 10 and $20 \mathrm{~m}$ and only $3.4 \%$ between 20 and $30 \mathrm{~m}$ (Fig. 4).

The 20 related individuals altogether left 36 markings $(1.8$ marks/individual), while the 5 unrelated individuals altogether left 21 markings (4.2 marks/individual) (Fig. 5). We found a statistical difference in marking rate between the expected and observed frequencies in related and unrelated individuals $\left(\chi^{2}=10.746, d f=1, P<0.05\right)$ (Table 2).

\section{Discussion}

Peters and Mech (1975) revealed that in wolves, territorial scent marking is done primarily by the parental pair, while other members of family groups play a minor role. Our study, however, confirms that all members of wolf family groups leave scats and urine on roads. We are aware that not all defecations and urinations are left to serve as scent markings. Nonetheless, the accumulation of scats and urine from various but related individuals is itself clear information about the strength of the group and may deter potential intruders. In aggressive interactions between neighbouring wolf family groups, the odds of a pack displacing its opponent are greatly improved by its size (Gese 2001), and groups with more old individuals or adult males have higher

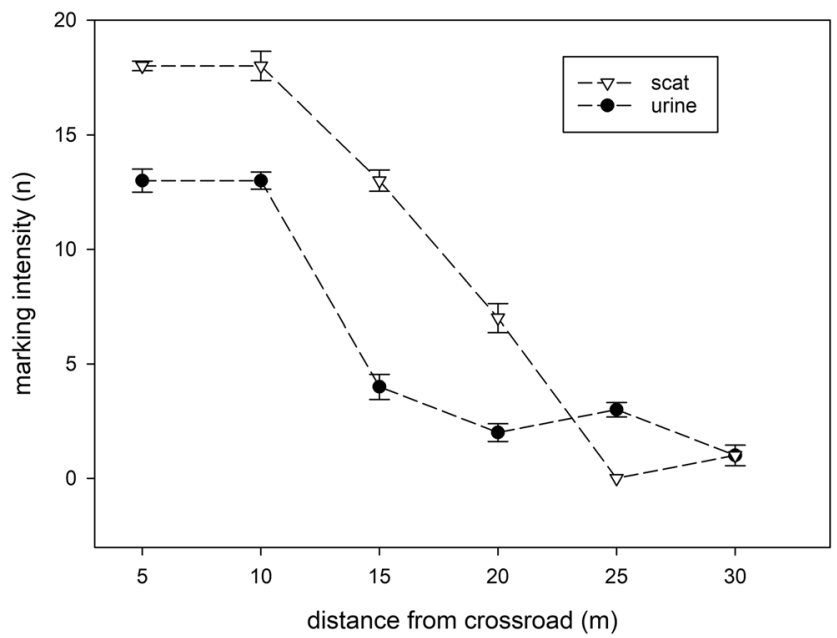

Fig. 3 Distance and density of all types of scent markings on the periphery of a crossroad chances of winning even with a numerical disadvantage (Cassidy et al. 2015). Scent marks may indicate the identity of individuals, including information on sexual status and age (Johnson 1973); thus, intruders discovering scats and urine of various individuals may also acquire information about the number and composition of the group inhabiting a given territory, allowing them to assess their chances of winning in potential aggressive encounters.

In carnivores, the frequency of marking varies with an individual's reproductive status, being the most intensive during the mating season (Macdonald 1980). Our observations show a high frequency of marking in a female with signs of heat, i.e. a female with oestrous blood in the urine. This female was unrelated to any of the wolf family groups living in the study area, and still showed a high rate of scent markings (urine with blood), which may suggest that she was looking for a male to form a pair (Russell, Rothman and Mech 1979). At the same time, three unrelated males left markings near hers, suggesting that she may have been the reason of this behaviour. The difference between the marking rates of full residents of territories and unrelated wolves was statistically significant; however, the majority of unrelated markings were left by only two individuals. Wolf packs generally are composed of family units consisting of a mated pair and their offspring of one or more years (Mech and Boitani 2003). The individuals that did not show any genetic relationship with the identified families, we assumed to be floaters. Floating wolves may be old animals that left their former packs or young dispersing individuals trying to acquire their own territories (Mech and Boitani 2003). Nonetheless, they represent an important reproductive buffer, as they can readily replace losses of resident family breeders (Fuller et al. 2003). As a result, it is difficult to assess whether this behaviour is specific for all floaters or just for those particular individuals. Further studies are necessary to explore this issue.

Our study confirms earlier suggestions (Peters and Mech 1975; Vilà et al. 1994; Barja et al. 2004; Zub et al. 2003) that forest crossroads and their immediate vicinities play a crucial role in wolf scent marking, as in other canids (Barja et al. 2001; Barja and List 2014); however, it also highlighted the possible impact of a higher human presence on wolf behaviour in more anthropogenic landscapes. In Ramuki-Napiwoda Forest, three important factors influenced the intensity of marking: distance from crossroad, the number of roads leaving crossroads and road driveability. There was a higher chance of finding both types of 
Fig. 4 Marking intensity (number of markings/number of crossroads) with scats and urine on all scent marked crossroads, simple crossroads and multiply crossroads. Means $( \pm \mathrm{SE})$ are based on the number of scent markings found on each crossroad type. Number of crossroads are indicated at the top of the column

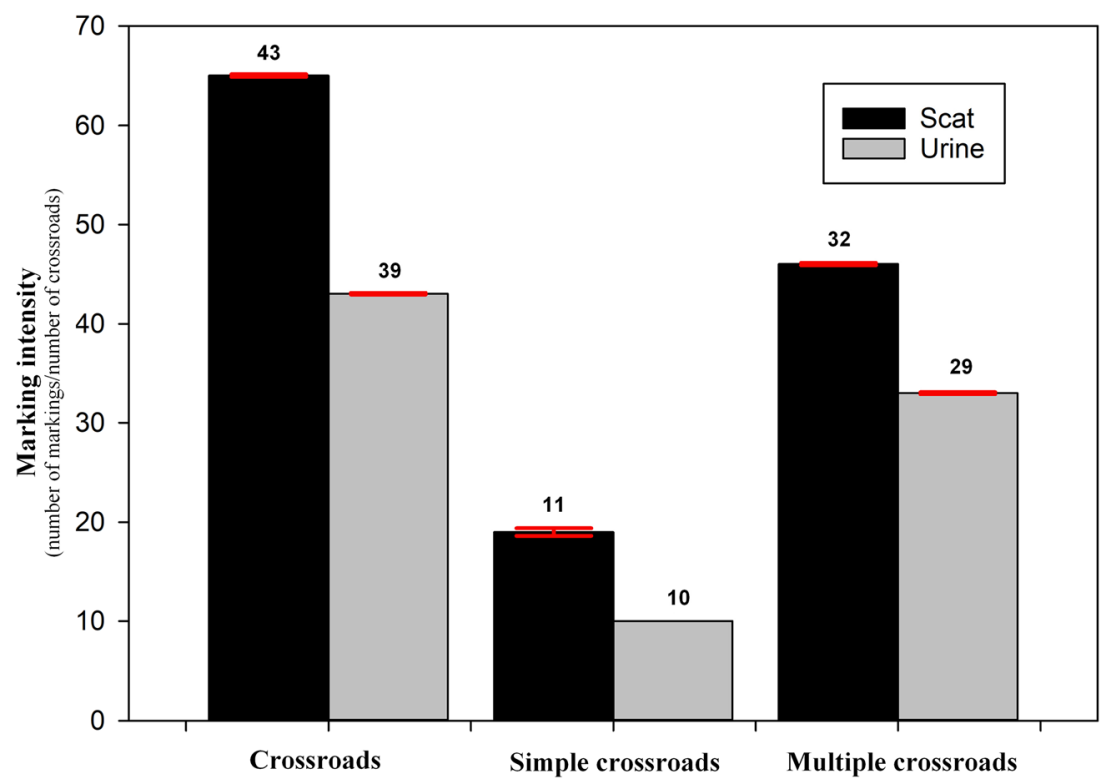

markings close (between 0 and $10 \mathrm{~m}$ ) to crossroads, and this was true up to $20 \mathrm{~m}$ from a crossroad for urinations and up to $25 \mathrm{~m}$ for defecations. Since wolves actively search for markings as they enter crossroads (Barja et al. 2004), this relationship seems to be logical, as markings left near the joining of roads will have a higher probability of being detected than those left further away. Wolves readily use dirt roads to facilitate their movement (Bojarska et al. 2020), which increases their prey search rate (Whittington et al. 2011; Dickie et al. 2017). Thus, more intensive marking of multiple crossroads maximizes the efficiency of their olfactory communication. The rate of a marking is also dependent on the type of crossroads. Significantly more markings were found at crossroads of roads passable only with fourwheel drive cars (type 2). The higher intensity of traffic on the better quality roads probably increases the probability markings are destroyed. This may also explain why on cross roads with high driveability (type 1) we found few scats in general and a higher frequency of urine marks compared to scats.

There are differences between the parts within a wolf territory that are most often marked between our study and study areas in Spain (Barja et al. 2004) and Bialowieza Primeval Forest (Zub et al. 2003). In Spain, the highest number of scats was left on crossroads while in Bialowieza Primeval Forest and our study, the highest marking intensity (scat and urine) occurred within the periphery of crossroad. This variation may be the result of the lower number of crossroads $/ \mathrm{km}$ in Barja et al. (2004) study (0.12 crossroad $/ \mathrm{km}$ ) compared to 1.12 crossroad $/ \mathrm{km}$ in our study area. Additionally, comparing the number of markings $/ \mathrm{km}$ on
Fig. 5 Marking intensity (number of markings/number of crossroads) with scats and urine on all scent marked crossroads, type one (easy crossroads, high driveability), type 2 (medium crossroads, medium driveability) and type 3 (difficult crossroads, low driveability). Means ( \pm SE) are based on number of scent markings found on each crossroads type. Number of crossroads are indicated at the top of the column

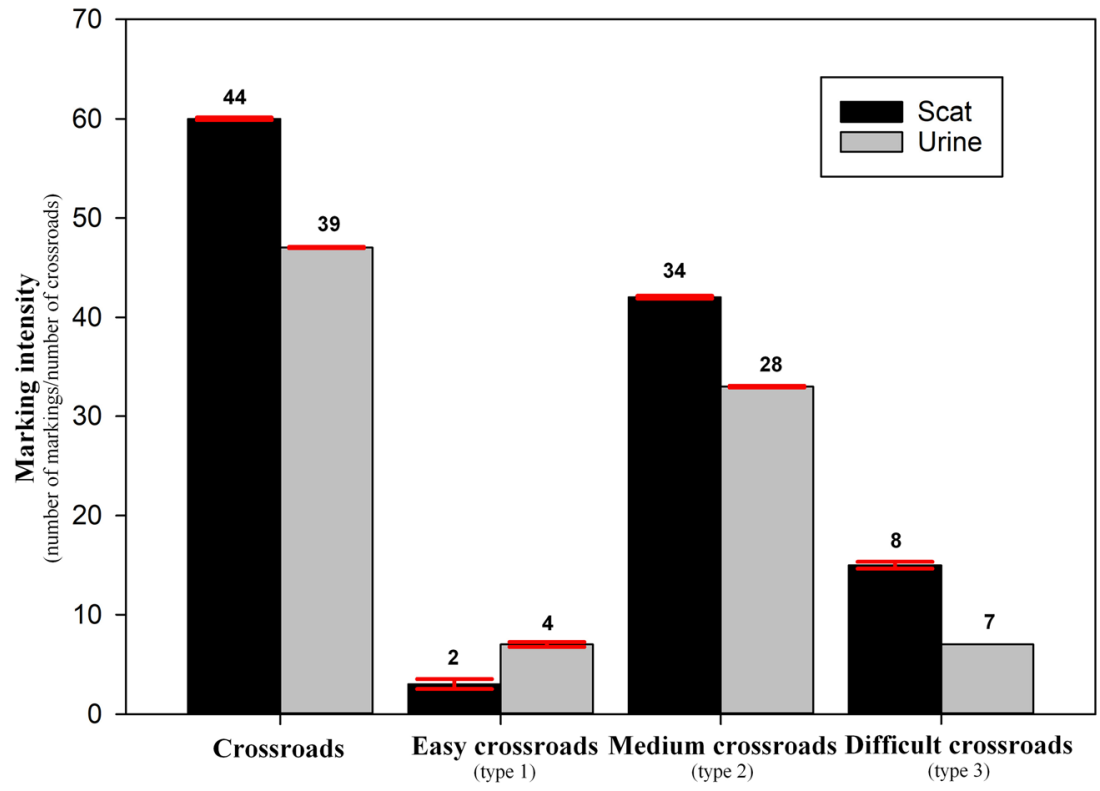


crossroads and peripheries of crossroad and roads in Spain (8.3, 1.67 and 0.15 , respectively; 10.12 in total) with those observed in our study $(1.5,3.4$ and 0.15 , respectively, 5.05 in total) suggests that wolves studied by Barja et al. (2004) were 2 times more intensive marking than wolves inhabiting managed lowland forests in Poland. In general, the results of our study are concordant with those of Barja et al. (2004) as in both areas, wolves prefer to deposit their markings on forest road junctions or in their near vicinity. In more detail, we can find a higher deposition of markings on the periphery in contrast to Barja et al. (2004), but still close to the crossroad. This may be indicative of a behavioural adaptation of wolves that live in areas with higher human presence, where scats at the periphery may have a bigger chance to be found by other individuals and less chance of being destroyed by vehicles. On the contrary, some of our results contrast with those of Bojarska et al. (2020) who reported that a majority of scats and minority of urine markings were found on high driveability roads, with these high-traffic forest roads offering the highest probability of finding wolf scats. Therefore, it is possible that other factors, e.g. the presence of different wolf packs, landform or behavioural patterns inherited from natal family groups, are more important for wolves in maintaining territories and that human presence plays a minor role. Wolf scent marking patterns are still poorly understood, and thus, there is a necessity for further research.

Besides providing insights into patterns of territory marking, the results of our study are useful for the monitoring of wolf populations based on the collection of indirect signs of wolf presence or non-invasive genetic samples (Reinhardt et al. 2015). During field work, special attention should be paid to forest road intersections, which serve as marking hot spots. Due to the higher activity of wolves at junctions, they are also a good place for mounting camera traps. Such an approach seems to be the most cost-effective for obtaining valuable data on wolf presence in managed forests characterized by high forest road density.

Acknowledgments We applied the "first-last-author-emphasis" norm for the sequence of authors.

Funding information Robert W. Mysłajek was supported by the National Science Centre, Poland (grant No. DEC-2014/12/S/NZ8/00624). Genetic analyses were supported by the Association for Nature "Wolf".

\section{Compliance with ethical standards}

Conflict of interest The authors declare that they have no conflict of interest.

Open Access This article is licensed under a Creative Commons Attribution 4.0 International License, which permits use, sharing, adaptation, distribution and reproduction in any medium or format, as long as you give appropriate credit to the original author(s) and the source, provide a link to the Creative Commons licence, and indicate if changes were made. The images or other third party material in this article are included in the article's Creative Commons licence, unless indicated otherwise in a credit line to the material. If material is not included in the article's Creative Commons licence and your intended use is not permitted by statutory regulation or exceeds the permitted use, you will need to obtain permission directly from the copyright holder. To view a copy of this licence, visit http://creativecommons.org/licenses/by/4.0/.

\section{References}

Andersen LW, Harms V, Caniglia R, Czarnomska SD, Fabbri E, Jędrzejewska B, Kluth G, Madsen AB, Nowak C, Pertoldi C, Randi E, Reinhardt I, Stronen AV (2015) Long-distance dispersal of a wolf, Canis lupus, in northwestern Europe. Mamm Res 60(3): 271. https://doi.org/10.1007/s13364-015-0220-6

Asa CS, Mech LD, Seal US (1984) The use of urine, faeces, and analgland secretions in scent-marking by a captive wolf (Canis lupus) pack. Anim Behav 33:1034-1036. https://doi.org/10.1016/S00033472(85)80043-9

Asa CS, Mech LD, Seal US, Plotka ED (1990) The influence of social and endocrine factors on urine-marking by captive wolves (Canis lupus). Horm Behav 24:497-509. https://doi.org/10.1016/0018506X(90)90038-Y

Barja I, List R (2014) The role of spatial distribution of faeces in coyote scent marking behaviour. Polish J Ecol 62:373-384. https://doi.org/ 10.3161/104.062.0215

Barja I, De Miguel FJ, Bárcena F (2001) Distribución espacial de los excrementos de zorro rojo (Vulpes vulpes, Linnaeus 1758) en los Montes do Invernadeiro (Ourense). Galemys 13:171-178 http:// www.secem.es/wp-content/uploads/2013/03/Galemys-13-NE-16Barja-et-al-171-178.pdf

Barja I, De Miguel FJ, Bárcena F (2004) The importance of crossroads in faecal marking behaviour of the wolves (Canis lupus). Naturwissenschaften 91:489-492. https://doi.org/10.1007/s00114004-0557-1

Barja I, De Miguel FJ, Bárcena F (2005) Faecal marking behaviour of Iberian wolf in different zones of their territory. Folia Zool 54:21-29 http://www.ivb.cz/folia_zoologica/archive/54_21-29.pdf

Barja I, Silván G, Illera JC (2008a) Relationships between sex and stress hormone levels in feces and marking behaviour in a wild population of Iberian wolves (Canis lupus signatus). J Chem Ecol 34:697-701 https://link.springer.com/article/10.1007/s10886-008-9460-0

Barja I, Silván G, Rosellini S, Piñeiro A, Illera MJ, Illera JC (2008b) Quantification of sexual steroid hormones in faeces of Iberian wolf (Canis lupus signatus): a non invasive sex typing method. Reprod Domest Anim 4:701-707. https://doi.org/10.1111/j.1439-0531. 2007.00974.x

Berger J (2007) Fear, human shields and the redistribution of prey and predators in protected areas. Biol Lett 3(6):620-623. https://doi.org/ 10.1098/rsbl.2007.0415

Blanco JC, Cortés Y, Virgós E (2005) Wolf response to two kind of barriers in an agricultural habitat in Spain. Can J Zool 83(2):313323. https://doi.org/10.1139/z05-016

Boitani L, Alvarez F, Anders O, Andren H, Avanzinelli E, Balys V, Blanco JC, Breitenmoser U, Chapron G, Ciucci P, Dutsov A, Groff C, Huber D, Ionescu O, Knauer F, Kojola I, Kubala J, Kutal M, Linnell J, Majic A, Mannil P, Manz R, Marucco F, Melovski D, Molinari A, Norberg H, Nowak S, Ozolins J, Palazon S, Potocnik H, Quenette P-Y, Reinhardt I, Rigg R, Selva N, Sergiel A, Shkvyria M, Swenson J, Trajce A, Von Arx M, Wolfl M, Wotschikowsky U, Zlatanova D (2015) Key actions for large carnivore populations in Europe. Institute of Applied Ecology. Report to DG Environment, European Commission, Bruxelles. http://ec.europa.eu/environment/ 
nature/conservation/species/carnivores/pdf/key_actions_large carnivores_2015.pdf

Bojarska K, Sulich J, Bachmann S, Okarma H, Theuerkauf J, Gula R (2020) Opportunity and peril: how wolves use a dense network of forest roads. Mamm Biol 100:203-211. https://doi.org/10.1007/ s42991-020-00014-0

Borowik T, Cornulier T, Jedrzejewska B (2013) Environmental factors shaping ungulate abundances in Poland. Acta Theriol 58:403-413. https://doi.org/10.1007/s13364-013-0153-x

Campos-Candela A, Palmer M, Balle S, Alós J (2017) A camera-based method for estimating absolute density in animals displaying home range behaviour. J Anim Ecol 87(3):825-837. https://doi.org/10. 1111/1365-2656.12787

Cassidy KA, MacNulty DR, Stahler DR, Smith DW, Mech LD (2015) Group composition effects on aggressive interpack interactions of gray wolves in Yellowstone National Park. Behav Ecol 26:13521360. https://doi.org/10.1093/beheco/arv081

Chapron G, Kaczensky P, Linnell JDC, von Arx M, Huber D, Andrén H, López-Bao JV, Adamec M, Álvares F, Anders O, Balčiauskas L, Balys V, Bedő P, Bego F, Blanco JC, Breitenmoser U, Brøseth H, Bufka L, Bunikyte R, Ciucci P, Dutsov A, Engleder T, Fuxjäger C, Groff C, Holmala K, Hoxha B, Iliopoulos Y, Ionescu O, Jeremić J, Jerina K, Kluth G, Knauer F, Kojola I, Kos I, Krofel M, Kubala J, Kunovac S, Kusak J, Kutal M, Liberg O, Majić A, Männil P, Manz R, Marboutin E, Marucco F, Melovski D, Mersini K, Mertzanis Y, Mysłajek RW, Nowak S, Odden J, Ozolins J, Palomero G, Paunović M, Persson J, Potočnik H, Quenette P-Y, Rauer G, Reinhardt I, Rigg R, Ryser A, Salvatori V, Skrbinšek T, Stojanov A, Swenson JE, Szemethy L, Trajçe A, Tsingarska-Sedefcheva E, Váňa M, Veeroja R, Wabakken P, Wölfl M, Wölfl S, Zimmermann F, Zlatanova D, Boitani L (2014) Recovery of large carnivores in Europe's modern human-dominated landscapes. Science 346: 1517-1519. https://doi.org/10.1126/science.1257553

Ciucci P, Boitani L, Francisci F, Andreoli G (1997) Home range, activity and movements of a wolf pack in central Italy. J Zool 243:803819. https://doi.org/10.1111/j.1469-7998.1997.tb01977.x

Czarnomska S, Jędrzejewska B, Borowik T, Niedziałkowska M, Stronen AV, Nowak S, Mysłajek RW, Okarma H, Konopiński M, Pilot M, Śmietana W, Caniglia R, Fabbri E, Randi E, Pertoldi C, Jẹdrzejewski W (2013) Concordant mitochondrial and microsatellite DNA structuring between Polish lowland and Carpathian Mountain wolves. Conserv Genet 14:73-588. https://doi.org/10. 1007/s10592-013-0446-2

de Groot GA, Nowak C, Skrbinsek T, Andersen LW, Aspi J, Fumagali L, Godinho R, Harms V, Jansman HAH, Liberg O, Marucco F, Mysłajek RW, Nowak S, Pilot M, Randi E, Reinhardt I, Śmietana W, Szewczyk M, Taberlet P, Vilá C, Munoz-Fuentes V (2016) Decades of population genetic research call for harmonization of molecular markers: the grey wolf, Canis lupus, as a case study. Mamm Revi 46:44-59. https://doi.org/10.1111/mam.12052

Demma D, Barber-Meyer S, Mech LD (2007) Testing global positioning system telemetry to study wolf predation on deer fawns. J Wildlife Manag 71(8):2767-2775. https://doi.org/10.2193/2006-382

Dickie M, Serrouya R, McNay RS, Boutin S (2017) Faster and farther: wolf movement on linear features and implications for hunting behaviour. J Appl Ecol 54:253-263. https://doi.org/10.1111/13652664.12732

Diserens TA, Borowik T, Nowak S, Szewczyk M, Niedźwiecka N, Mysłajek RW (2017) Deficiencies in Natura 2000 for protecting recovering large carnivores: a spotlight on the wolf Canis lupus in Poland. PLoS One 12(9):e0184144. https://doi.org/10.1371/journal. pone. 0184144

Fabbri E, Miquel C, Lucchini V, Santini A, Caniglia R, Duchamp C, Weber J-M, Lequette B, Marucco F, Boitani L, Fumagali L, Taberlet P, Randi E (2007) From the Apennines to the Alps: colonization genetics of the naturally expanding Italian wolf (Canis lupus) population. Mol Ecol 16:1661-1671. https://doi.org/10. 1111/j.1365-294X.2007.03262.x

Francisco LV, Langston AA, Mellersh CS, Neal CL, Ostrander EA (1996) A class of highly polymorphic tetranucleotide repeats for canine genetic mapping. Mamm Genome 7:359-362. https://doi. org/10.1007/s003359900104

Fredholm M, Wintero AK (1995) Variation of short tandem repeats within and between species belonging to the Canidae Family. Mamm Genome 6:11-18. https://doi.org/10.1007/BF00350887

Fritts SH, Bangs EE, Fontaine JA, Johnson MR, Phillips MK, Koch ED, Gunson JR (1997) Planning and implementing a reintroduction of wolves to Yellowstone National Park and Central Idaho. Restor Ecol 5:7-27. https://doi.org/10.1046/j.1526-100X.1997.09702.x

Fuller TK, Mech LD, Cochrane JF (2003) Wolf population dynamics. In: Mech LD, Boitani L (eds) Wolves behaviour, ecology, and conservation. University of Chicago Press, Chicago, pp 161-191

Gełdoń A, Nowak S, Mysłajek RM (2015) Sprawozdanie z inwentaryzacji dużych drapieżników w sezonie 2014/2015 w wybranych nadleśnictwach Regionalnej Dyrekcji Lasów Państwowych w Olsztynie oraz Regionalnej Dyrekcji Lasów Państwowych w Białymstoku. Olsztyn, 2015. ISBN 978-83-9040-534-6

Gese EM (2001) Monitoring of terrestial carnivores. In: Gittleman JL, Funk SM, MacDonald DW, Wayne RK (eds) Carnivore conservation. Cambridge University Press \& The Zoological Society of London, Cambridge, pp 372-396

Harrington FH (1981) Urine-marking and caching behaviour in the wolf (Canis lupus). Behaviour 76:280-288

Harrington F, Asa C (2003) Wolf communication. In: Mech LD, Boitani L (eds) Wolves behaviour, ecology, and conservation. University of Chicago Press, Chicago, pp 93-94

Huck M, Jęrzzejewski W, Borowik T, Jẹdrzejewska B, Nowak S, Mysłajek RW (2011) Analyses of least cost paths for determining effects of habitat types on landscape permeability: wolves in Poland. Acta Theriol 56:91-101. https://doi.org/10.1007/s13364-010-0006-9

Iliopoulos Y, Youlatos D, Sgardelis S (2014) Wolf pack rendezvous site selection in Greece is mainly affected by anthropogenic landscape features. Eur J Wildl Res 60:23-34. https://doi.org/10.1007/s10344013-0746-3

Jędrzejewski W, Schmidt K, Theuerkauf J, Jędrzejewska B, Kowalczyk R (2007) Territory size of wolves Canis lupus: linking local (Białowieża Primeval Forest, Poland) and Holarctic-scale patterns. Ecography 30: 66-76. https://doi.org/10.1111/j.0906-7590.2007.04826.x

Jędrzejewski W, Jędrzejewska B, Zawadzka B, Borowik T, Nowak S, Mysłajek RW (2008) Habitat suitability model for Polish wolves Canis lupus based on long-term national census. Anim Conserv 11:377-390. https://doi.org/10.1111/j.1469-1795.2008.00193.x

Jędrzejewski W, Niedziałkowska M, Hayward MW, Goszczyński J, Jędrzejewska B, Borowik T, Bartoń KA, Nowak S, Harmuszkiewicz J, Juszczyk A, Kałamarz T, Kloch A, Koniuch J, Kotiuk K, Mysłajek RW, Nędzyńska M, Olczyk A, Teleon M, Wojtulewicz M (2012) Prey choice and diet of wolves related to ungulate communities and wolf subpopulations in Poland. J Mammal 93:1480-1492. https://doi.org/ 10.1644/10-MAMM-A-132.1

Johnson RP (1973) Scent marking in mammals. Anim Behav 21:521535. https://doi.org/10.1126/science.171.3970.443

Jones O, Wang J (2010) COLONY: a program for parentage and sibship inference from multilocus genotype data. Mol Ecol Resour 10:551555. https://doi.org/10.1111/j.1755-0998.2009.02787.x

Kalinowski ST, Taper ML, Marshall TC (2007) Revising how the computer program cervus accommodates genotyping error increases success in paternity assignment. Mol Ecol 16(5):1099-1106. https://doi.org/10.1111/j.1365-294X.2007.03089.x

Kleiman DG (1966) Scent marking in the Canidae. Symp Zool Soc Lond 18:167-177

Kojola I, Heikkinen S, Holmala K (2018) Balancing costs and confidence: volunteer-provided point observations, GPS telemetry and 
the genetic monitoring of Finland's wolves. Mammal Res 63:415423. https://doi.org/10.1007/s13364-018-0371-3

Kuijper DPJ, Sahlén E, Elmhagen B, Chamaillé-Jammes S, Sand H, Lone K, Cromsigt JPGM (2016) Paws without claws? Ecological effects of large carnivores in anthropogenic landscapes. Proc R Soc B 283: 16-25. https://doi.org/10.1098/rspb.2016.1625

Kusak J, Majić Skrbinšek A, Huber D (2005) Home ranges, movements, and activity of wolves (Canis lupus) in the Dalmatian part of Dinarids, Croatia. Eur J Wildl Res 51:254-262. https://doi.org/10. 1007/s10344-005-0111-2

Llaneza L, García EJ, López-Bao JV (2014) Intensity of territorial marking predicts wolf reproduction: implications for wolf monitoring. PLoS One 9(3):e93015. https://doi.org/10.1371/journal.pone.0093015

Macdonald DW (1980) Patterns od scent marking with urine and faeces amongst carnivore communities. Symp Zoo Soc Lond 45:107-139

Martín J, Barja I, López P (2010) Chemical scent constituents in feces of wild Iberian wolves (Canis lupus signatus). Biochem Syst Ecol 38: 1096-1102. https://doi.org/10.1016/j.bse.2010.10.014

Mattisson J, Sand H, Wabakken P, Gervasi V, Liberg O, Linnell JDC, Rauset GR, Pedersen HC (2013) Home range size variation in a recovering wolf population: evaluating the effect of environmental, demographic, and social factors. Oecologia 173:813-825. https:// doi.org/10.1007/s00442-013-2668-x

Mech LD, Boitani L (2003) Wolf social ecology. In: Mech LD, Boitani L (eds) Wolves behaviour, ecology, and conservation. University of Chicago Press, Chicago, pp 1-34

Merrill SB (2002) An evaluation of the use of global positioning system telemetry in studying wolf biology. Dissertation, University of Minnesota, Minneapolis

Mysłajek RW, Nowak S (2015) Not an easy road to success: the history of exploitation and restoration of the wolf population in Poland after World War Two. In: Masius M, Sprenger J (eds) Fairytaile in question: historical interactions between humans and wolves. White Horse Press, Cambridge, pp 247-258

Mysłajek RW, Tracz M, Tracz M, Tomczak P, Szewczyk M, Niedźwiecka N, Nowak S (2018) Spatial organization in wolves Canis lupus recolonizing north-West Poland: large territories at low population density. Mamm Biol 92:37-44. https://doi.org/10. 1016/j.mambio.2018.01.006

Neff MW, Broman KW, Mellersh CS, Ray K, Acland GM, Aguirre GD, Ziegle JS, Ostrander EA, Rine J (1999) A second-generation genetic linkage map of the domestic dog, Canis familiaris. Genetics 151: 803-820

Newsome TM, Dellinger JA, Pavey CR, Ripple WJ, Shores CR, Wirsing AJ, Dickman CR (2015) The ecological effects of providing resource subsidies to predators. Glob Ecol Biogeogr 24(1):111. https://doi.org/10.1111/geb.12236

Niedziałkowska M, Jędrzejewski W, Mysłajek RW, Nowak S, Jędrzejewska B, Schmidt K (2006) Environmental correlates of Eurasian lynx occurrence in Poland - large scale census and GIS mapping. Biol Conserv 133:63-69. https://doi.org/10.1016/j. biocon.2006.05.022

Nowak S, Mysłajek RW, Szewczyk M, Tomczak P, Borowik T, Jędrzejewska B (2017) Sedentary but not dispersing wolves Canis lupus recolonizing western Poland (2001-2016) conform to the predictions of a habitat suitability model. Divers Distrib 23:13531364. https://doi.org/10.1111/ddi.12621

Paquet PC (1991) Scent-marking behavior of sympatric wolves (Canis lupus) and coyotes (C. latrans) in Riding Mountain National Park. Can J Zool 69:1721-1727. https://doi.org/10.1139/z91-240

Paquet PC, Fuller WA (1990) Scent marking and territorially in wolves of riding mountain national park. In: McDonald DW, Muller-Schwarze D, Natynczuk SE (eds) Chemical signals in vertebrates 5. Oxford University Press, New York, pp 394-400

Peters RP, Mech LD (1975) Scent-marking in wolves. Am Sci 63:628-637
Phillips MK, Bangs EE, Mech LD, Kelly BT, Fazio BB (2004) Extermination and recovery of red wolf and grey wolf in the contiguous United States. In: Macdonald DW, Sillero-Zubiri C (eds) The biology and conservation of wild canids. Oxford University Press, Oxford, pp 297-309. https://doi.org/10.1093/acprof:oso/ 9780198515562.003 .0019

Reinhardt I, Gluth G, Nowak S, Mysłajek RW (2015) Standards for the monitoring of the Central European Wolf Population in Germany and Poland. Bundesamt für Naturschutz (BfN) Federal Agency for Nature Conservation, Bonn

Rothman RJ, Mech LD (1979) Scent-marking in lone wolves and newlyformed pairs. Anim Behav 27:750-760. https://doi.org/10.1016/ 0003-3472(79)90010-1

Sazatornil V, Rodríguez A, Klaczek M, Ahmadi M, Alvares F, Arthur S, Blanco JC, Borg BL, Cluff D, Cortés Y, García EJ, Geffen E, Habib B, Iliopoulos Y, Kaboli M, Krofel M, Llaneza L, Marucco F, Oakleaf JK, Person DK, Potočnik H, Ražen N, Rio-Maior H, Sand H, Unger D, Wabakken P, López-Bao JV (2016) The role of humanrelated risk in breeding site selection by wolves. Biol Conserv 201: 103-110. https://doi.org/10.1016/j.biocon.2016.06.022

Shibuya H, Collins BK, Huang THM, Johnson GS (1994) A polymorphic $($ Aggaat $)(\mathrm{N})$ tandem repeat in an intron of the canine VonWillebrand-factor gene. Anim Genet 25:122-122. https://doi.org/ 10.1111/j.1365-2052.1994.tb00094.x

Steinglein JL, Waits LP, Ausband DE, Zager P, Mack CM (2010) Efficient, non invasive genetic sampling for monitoring reintroduced wolves. J Wildl Managem 74:1050-1058. https://doi. org/10.2193/2009-305

Suraci JP, Clinchy M, Zanette LY, Wilmers CC (2019) Fear of humans as apex predators has landscape-scale impacts from mountain lions to mice. Ecol Lett 22(10):1578-1586. https://doi.org/10.1111/ele.13344

Szewczyk M, Nowak S, Niedźwiecka N, Hulva P, Špinkytė-Bačkaitienė R, Demjanovičová K, Bolfíková BČ́, Antal V, Fenchuk V, Figura M, Tomczak P, Stachyra P, Stępniak KM, Zwijacz-Kozica T, Mysłajek RW (2019) Dynamic range expansion leads to establishment of a new, genetically distinct wolf population in Central Europe. Sci Rep 9(1):19003. https://doi.org/10.1038/s41598-01955273-w

Taberlet P, Griffin S, Goossens B, Questiau S, Manceau V, Escaravage N, Waits LP, Bouvet J (1996) Reliable genotyping of samples with very low DNA quantities using PCR. Nucleic Acids Res 24(16): 3189-3194. https://doi.org/10.1093/nar/24.16.3189

Theuerkauf J, Jędrzejewski W, Schmidt K, Gula R (2003) Spatiotemporal segregation of wolves from humans in the Białowieża Forest (Poland). J Wildlife Manag 67(4):706-716. https://doi.org/10. 2307/3802677

Vilà C, Urios V, Castroviejo J (1994) Use of faeces for scent marking in Iberian wolves (Canis lupus). Can J Zool 72:374-377. https://doi. org/10.1139/z94-053

Whittington J, Hebblewhite M, DeCesare NJ, Neufeld L, Bradley M, Wilmshurst J, Musiani M (2011) Caribou encounters with wolves increase near roads and trails: a time-to-event approach. J Appl Ecol 48:1535-1542. https://doi.org/10.1111/j.1365-2664.2011.02043.x

Zub K, Theuerkauf J, Jędrzejewski W, Jędrzejewska B, Schmidt K, Kowalczyk R (2003) Wolf pack territory marking in the Białowieza Primeval Forest (Poland). Behaviour 140:635-648. https://doi.org/10.1163/156853903322149478

Lesniak I, Heckmann I, Heitlinger E, Szentiks CA, Nowak C, Harms V, Jarausch A, Reinhardt I, Kluth G, Hofer H, Krone O (2017) Population expansion and individual age affect endoparasite richness and diversity in a recolonising large carnivore population. Sci Rep 7:1-14. https://doi.org/10.1038/srep41730

Publisher's note Springer Nature remains neutral with regard to jurisdictional claims in published maps and institutional affiliations. 